\section{Never a cross word}

Foremost among the many satisfactions in editing ET are the contributors and the ways in which they come to be contributors.

One contributor has been quietly with us from the start, providing readers with verbal challenges in every issue. Frank Palmer is known worldwide in his more formal persona as F. R. Palmer, a noted grammarian of English and particularly of the English verb. Frank has been a marvel of steadiness, delivering puzzle upon puzzle for quarter after quarter. We recently agreed, how ever, that the old order does eventually change. Worldwide puzzlers competing for those excellent prizes (five every time) will be sorry to see the cryptic flow come to an end with the 66th puzzle in this 66 th issue. We have been lucky to have him sustain this brilliant work for such a long time. Many thanks, Frank.

In every issue I have been fascinated by the coming together of writers and topics, often planned but equally often coincidental, as people with similar interests just happen to submit related material at the same time. This was true of $\mathrm{Li}$ Lan and $\mathrm{Li}$ Yongyan, with their parallel email analyses in ET64, and also of Lee-Wong Song Mei, Andrew Preshous, and Su-Hie Ting, with their accidental medley on Singaporean and Malaysian English in ET65. I am used to interesting surprises, but that one is in a class of its own.

The current issue is no exception. Bryan Garner - with another contribution in a crucial area, plus another interesting comment from Andrew Dalby in The Linguist - has responded to my piece on editing and error in the last issue (extending our dialogue in important new ways). J oanna Radwanska-Williams and Eva Lai I met in early 2000 during a memorable semester at the Chinese University of Hong Kong. We talked and later emailed, and the results are an essay presenting (intensely and often poetically) a multilingual banyan-tree model of language, and (for the first time to my knowledge) an account of free-enterprise English in China. Rahela Banu and Roland Sussex I met at a lively conference on world English sponsored by OUP at the Australian National University in Canberra in late 1999. Now they present a report on English 'sign language' in Bangladesh that notably complements other 'international sign' articles we have published.

Tom McArthur

The editorial policy of English Today is to provide a focus or forum for all sorts of news and opinion from around the world. The points of view of individual writers are as a consequence their own, and do not reflect the opinion of the editorial board. In addition, wherever feasible, ET generally leaves unchanged the orthography (normally British or American) and the usage of individual contributors, although the editorial style of the journal itself is that of Cambridge University Press. (c) Cambridge University Press 2001 No contents may be reproduced by any means without the permission of Cambridge University Press.

English Today (ISSN 0266-0784) is a quarterly.

Publisher:

Cambridge University Press,

The Edinburgh Building, Cambridge CB2 2RU, United Kingdom. Telephone (01223) 312393 Email: journals marketing@cup.cam.ac.uk Subscriptions: the current annual subscription price for four issues for libraries and institutions is $\mathrm{f} 66$ outside North America; $£ 30$ for individuals; $£ 23$ for students and the retired. Prices include delivery by air where appropriate. Apply to Jane Crossland at the above address.

Advertising Sales: write to the Advertising Promoter at the above address.

USA, CANADA AND MEXICO: Publisher:

Cambridge University Press,

40 West 20th Street, New York NY 10011-4211, USA.

Telephone (212) 9243900. Subscriptions: the current annual subscription price in USA, Canada and Mexico for libraries and institutions is $\$ 103 ; \$ 50$ for individuals; $\$ 36$ for students and the retired. Apply to J oseph D. Hranek at the above address. Advertising Sales: write to the Advertising Coordinator at the above address.

Periodicals postage paid at New York, NY and at additional mailing offices.

POSTMASTER: send address changes in USA, Canada and Mexico to English Today, Cambridge University Press, 110 Midland Avenue, Port Chester, New York, NY 10573-4930, USA.

Japanese prices for institutions are available from Kinokuniya Company Ltd, P.O. Box 55, Chitose, Tokyo 156, Japan.

Letters to the Editor: write to Dr Tom McArthur, Editor, English Today, 22-23 Ventress Farm Court, Cherry Hinton Road, Cambridge CB1 4HD, UK. Tel 01223245934 , Fax 01223241161.

Email: Scotsway@aol.com

Internet access

This journal is included in the Cambridge Journals Online service which can be found at

http://uk.cambridge.org/journals. For further information on other Press titles access http://uk.cambridge.org.

Printed in the United Kingdom by the University Press, Cambridge 